\title{
HYDROGEN SULFIDE ACCUMULATION FACTORS IN COAL MINE OF SOUTHEASTERN MARGIN OF JUNGGAR BASIN IN CHINA
}

\author{
DENG, Q. ${ }^{1,2,3^{*}}-$ WEI, J. ${ }^{2,4}-\mathrm{LI}, \mathrm{H}^{2}{ }^{2}-\mathrm{WANG}, \mathrm{Y}^{2}-\mathrm{WU}, \mathrm{X}^{2}-\mathrm{LIU}, \mathrm{M} .^{1,2}$ \\ ${ }^{1}$ State Key Laboratory Cultivation Base for Gas Geology and Gas Control, Henan Polytechnic \\ University, 454003 Jiaozuo, P. R. China \\ ${ }^{2}$ School of Safety Science and Engineering, Henan Polytechnic University \\ 454003 Jiaozuo, P. R. China \\ ${ }^{3}$ Collaborative Innovation Center of Coal Safety Production of Henan Province \\ 454003 Jiaozuo, P. R. China \\ ${ }^{4}$ Key Laboratory of Public Security Management Technology, Shandong Management \\ University, 250357 Jinan, China \\ *Corresponding author \\ e-mail: dengqigen@hpu.edu.cn; phone: +86-391-398-6252; fax: +86-391-398-7881
}

(Received $12^{\text {th }}$ Oct 2018; accepted $19^{\text {th }}$ Nov 2018)

\begin{abstract}
Hydrogen sulfide provides an abundance anomaly in many coal mines (districts) in southeastern margin of Junggar basin in China. There are three sets of source rocks in this area, where the coal bearing strata mainly involve low metamorphic bituminous coals of the Xishan formation and the Badaowan formation with less than $45^{\circ} \mathrm{C}$ geotemperature, which is beneficial to the propagation of Sulfate-Reducing Bacteria. The average Sulfate-Reducing Bacteria value of samples is 791 grams / sample. Along with the runoff direction, the salinity and $\mathrm{pH}$ value of groundwater gradually increase. And the hydrochemical types of groundwater are evolved into $\mathrm{HCO}_{3}-\mathrm{SO}_{4}-\mathrm{Cl}-\mathrm{Na}$ by $\mathrm{HCO}_{3}-\mathrm{Ca}-\mathrm{Na}$ and $\mathrm{HCO}_{3}-\mathrm{SO}_{4}-\mathrm{Na}-\mathrm{Ca}$, with the main components of $\mathrm{NaHCO}_{3}$. In a reducing environment and with the hydrocarbon abundance, the bacterial sulfate reduction is prone to occur and $\mathrm{H}_{2} \mathrm{~S}$ is likely to form. Meanwhile, the better pore types of the reservoir are mainly the intergranular pore and intragranular dissolved pore. The average porosity of each coal seam is about $8.5 \% /$ porosity values are medium, the average permeability is $(5.36 \times 10-3 \sim 11.6 \times 10-3) \mathrm{um} 2 /$ permeability values are low. The top and bottom slates of coal seam are mainly composed of fine clastic rock and low permeability barrier with the characteristics of good sealing ability. All of this provides a wide space for the reservoir of $\mathrm{H}_{2} \mathrm{~S}$, under the action of groove type subsidence structure, uplift type relief structures and the hydrodynamic control of methane. Two types of $\mathrm{H}_{2} \mathrm{~S}$ accumulation mode of northward monoclinic and imbricated fan-shaped ware formed in specific geological condition.
\end{abstract}

Keywords: hydrogen sulfide $\left(\mathrm{H}_{2} \mathrm{~S}\right)$, control factors, accumulation model, underground water, regional structure

\section{Introduction}

Many mining areas in the southeastern margin of the Junggar basin are abundant anomaly with $\mathrm{H}_{2} \mathrm{~S}$, resulting in many casualties (Deng et al., 2017). The accumulation model of $\mathrm{H}_{2} \mathrm{~S}$ in regional coal mines is explored to study the formation, accumulation, and preservation of $\mathrm{H}_{2} \mathrm{~S}$ in the area in order to provide geology-geochemical basis for occurrence characteristics and prevention of $\mathrm{H}_{2} \mathrm{~S}$ in coal rock. At present, domestic and foreign scholars have conducted many researches on the $\mathrm{H}_{2} \mathrm{~S}$ accumulation model in oil and gas from the aspects of regional structure, reservoir characteristics, sedimentary 
systems, etc. (Zhu et al., 2006; Fei et al., 2010; Fu et al., 2006; Cai et al., 2009). However, there are few studies on the accumulation mode of $\mathrm{H}_{2} \mathrm{~S}$ in coal mine. The purpose of this study is to find the controlling factors of hydrogen sulfide occurrence in this region and provide the research basis for the treatment and the genesis of hydrogen sulfide.

\section{Methods}

Collect data according to drilling data, seismic interpretation data, engineering geology, etc. Analyze features of regional geological, sedimentary and structural evolution. Identify regional features and hydrogen sulfide distribution status.

According to the regional geological characteristics, combined with the nature of hydrogen sulfide reservoir, underground water activities in coal mine and chemical characteristics of underground water (hot spring), the storage conditions of hydrogen sulfide gas and the control factors of abnormal enrichment were identified.

\section{Structural geological background}

The southeastern margin of Junggar basin lies between the Santun river and the Sigong river in Fukang county. Located in the middle-east section of the Urumchi front depression, its structural division belongs to the front depression area of south margin of Junggar basin with the formation of north steep slope (dip angle of $70 \sim 80^{\circ}$ ) and the shape of the southern latitude (dip angle $40 \sim 50^{\circ}$ ) (Qin, 1987). Regional distribution ranges from Liuhuanggou in the east to Shuimogou and Sigong River in the west via Toutun river, Xishan coal mine and north of Urumchi city. The regional geology conditions is summarized in Figure 1.

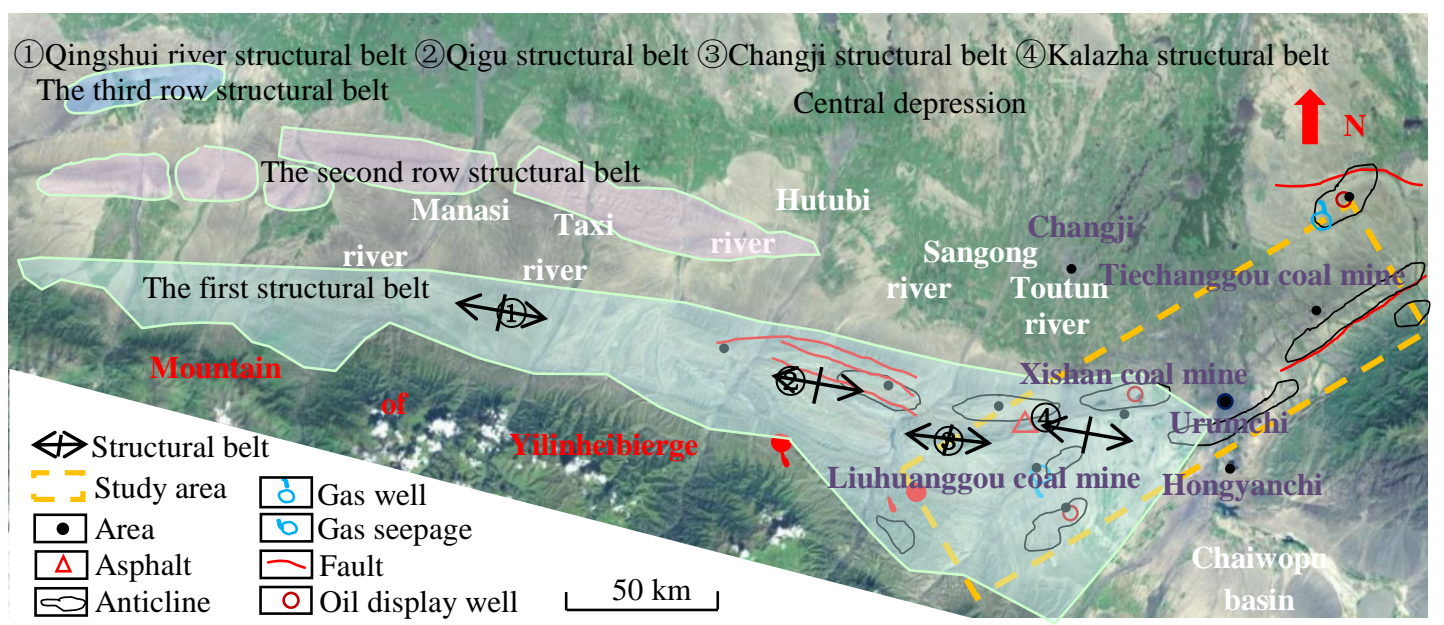

Figure 1. Regional geology conditions

The low-metamorphic bituminous coal was mainly developed in Xishanyao formation $\left(\mathrm{J}_{2} \mathrm{X}\right)$ and Badaowan formation $\left(\mathrm{J}_{1} \mathrm{~b}\right)$ of early-middle Jurassic (Tian and Yang, $2011)$ in this district. The Badaowan formation contains 8 50 layers of coal seams with $8 \sim 12$ layers of minable coal seams and its total thickness of 14.9 22.8 m. Xishanyao formation contains 3 57 layers of coal seams with 12 20 layers of minable coal seams and its total thickness of 35.6 145.8 m. 


\section{Formation mode of $\mathrm{H}_{2} \mathrm{~S}$}

$\mathrm{H}_{2} \mathrm{~S}$ can be generated through biochemical degradation of early peat accumulation, bacterial sulfate reduction (BSR) in peat accumulation period and at the stage of coal formation, thermochemical sulfate reduction (TSR) during coal evolution, thermal decomposition sulfides (TDS) and magma (volcanic eruption) activity (Liu et al., 2012; Machel, 2001; Worden et al., 1995).

This region have formed 3 sets of effective source rocks of the Lower Cretaceous Tugulu Group, Middle and Lower Jurassic Period (Badaowan formation and Xishanyao formation) and Middle Permain (Guo et al., 2013). The intensity of source rocks gasgeneration in the Middle Permian can reach to $5.0 \times 10^{8} \sim 40.0 \times 10^{8} \mathrm{~m}^{3} / \mathrm{km}^{2}$. The average organic carbon content of dark mudstone in source rocks in the Middle-Lower Jurassic is $15.51 \%$. And the average organic carbon content in coal is as high as $64.49 \%$. The source rocks isopaches of Lower Jurassic is shown in Figure 2, in which the organic matrix of Xishanyao formation, mainly composed of 0-II humus, is in a low maturemature stage. The abundant source rocks provide a solid material basis for the production of $\mathrm{H}_{2} \mathrm{~S}$.

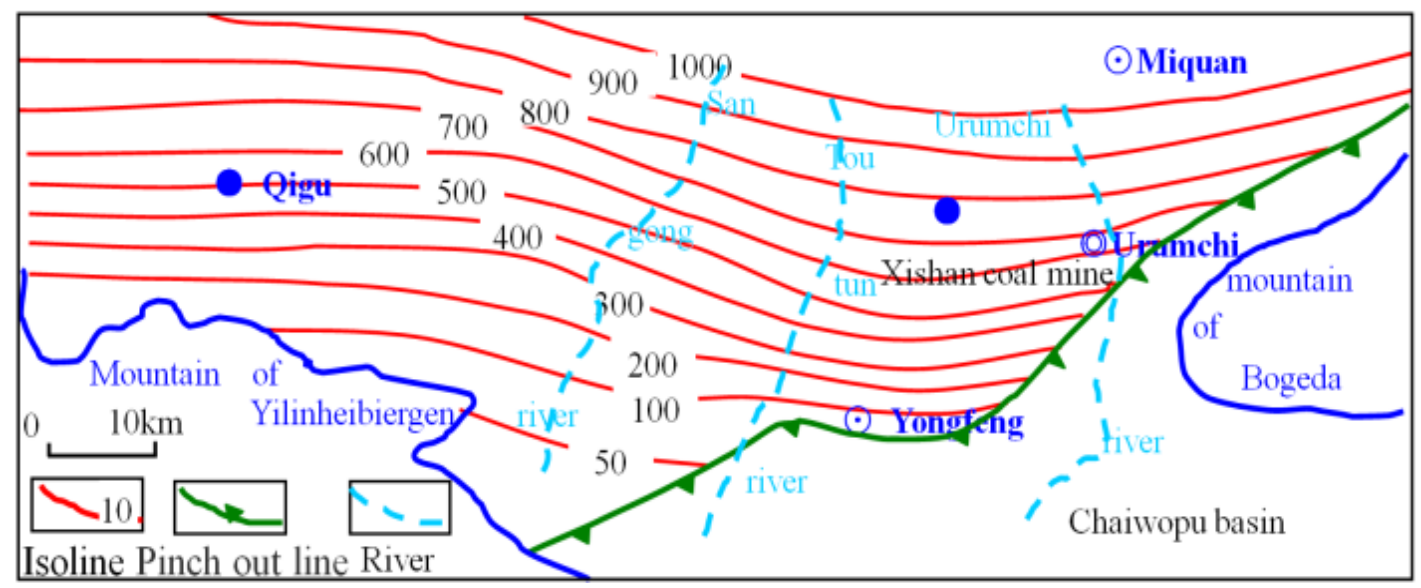

Figure 2. Source rocks isopaches of Lower Jurassic

In southern region, the melted snow and ice on the peak of Yilinheibiergen Mountain and Bogeda Mountain flow along the direction of runoff. During its infiltration and runoff, the water dissolves and lixiviates with the anorthite and albite, which is likely to occur chemical reactions, as shown in Equations 1-4. Under strong drought evaporation, it may form the high salinity waters type of $\mathrm{HCO}_{3}-\mathrm{Ca}-\mathrm{Na}, \mathrm{HCO}_{3}-\mathrm{SO}_{4}-\mathrm{Na}-\mathrm{Ca}$ and $\mathrm{HCO}_{3}-\mathrm{SO}_{4}-\mathrm{Cl}-\mathrm{Na}-\mathrm{K}$.

$$
\begin{gathered}
\mathrm{CaCO}_{3} \cdot 2 \mathrm{Al}_{2} \mathrm{O}_{3} \cdot 4 \mathrm{SiO}_{2} \text { (Anorthite) }+2 \mathrm{CO}_{2}+5 \mathrm{H}_{2} \mathrm{O} \rightarrow 2 \mathrm{HCO}_{3}{ }^{-}+\mathrm{Ca}^{2+}+2 \mathrm{H}_{4} \mathrm{Al}_{2} \mathrm{Si}_{2} \mathrm{O}_{9} \\
\mathrm{Na}_{2} \mathrm{Al}_{2} \mathrm{Si}_{6} \mathrm{O}_{16} \text { (Albite) }+2 \mathrm{CO}_{2}+3 \mathrm{H}_{2} \mathrm{O} \rightarrow 2 \mathrm{HCO}_{3}{ }^{-}+2 \mathrm{Na}^{2+}+2 \mathrm{H}_{4} \mathrm{Al}_{2} \mathrm{Si}_{2} \mathrm{O}_{9}+4 \mathrm{SiO}_{2} \\
\mathrm{CaSO}_{4} \rightarrow \mathrm{Ca}^{2+}+\mathrm{SO}_{4}{ }^{2-} \\
\mathrm{NaCl} \rightarrow \mathrm{Na}^{+}+\mathrm{Cl}^{-}
\end{gathered}
$$


Most of coal seams are low rank coal with the shallow buried depth in the region. And in the coal and rock formations, the microbial activity is more common. From the sampling depth of 254 750 $\mathrm{m}$ in each mine, the measured number of Sulfate-Reducing Bacteria (SRB) was $(100 \sim 3500) / \mathrm{g} \cdot$ samples with an average of $791 / \mathrm{g} \cdot$ samples. In the Xiaolongkou coal mine, the measured number of SRBs was $3500 / \mathrm{g} \cdot \mathrm{samples}$ at $312 \mathrm{~m}$ below the well. The number of SRBs was $528 / \mathrm{g}$. samples at $750 \mathrm{~m}$ below in the Xishan coal mine and the number of SRBs was $650 / \mathrm{g}$. samples at $209.5 \mathrm{~m}$ below in the Beishan coal mine. It shows that the current depth of mining is conducive to the proliferation of SRB (Deng et al., 2018).

The groundwater environment of coal mine in the region is well-sealed. In the reducing environment, the influence of SRB and the sufficient hydrocarbon organic matter ( $\Sigma \mathrm{CH}, \mathrm{C})$, BSR may occur (Headd and Engel, 2013), and then $\mathrm{H}_{2} \mathrm{~S}$ is formed. Its possible reactions are showed in Equations 5-8.

$$
\begin{gathered}
\sum \mathrm{CH}(\mathrm{C})+\mathrm{SO}_{4}{ }^{2-}+\mathrm{H}_{2} \mathrm{O} \rightarrow \mathrm{H}_{2} \mathrm{~S} \uparrow+\mathrm{CO}_{2} \uparrow+\mathrm{CO}_{3}{ }^{2-} \\
\mathrm{CH}_{4}+\mathrm{SO}_{4}{ }^{2-} \rightarrow \mathrm{HS}^{-}+\mathrm{HCO}_{3}{ }^{-}+\mathrm{H}_{2} \mathrm{O} \\
\mathrm{CH}_{4}+\mathrm{CaSO}_{4} \rightarrow \mathrm{CaCO}_{3} \downarrow+\mathrm{H}_{2} \mathrm{~S} \uparrow+\mathrm{H}_{2} \mathrm{O} \\
\mathrm{CH}_{4}+\mathrm{SO}_{4}{ }^{2-} \rightarrow \mathrm{CO}_{2} \uparrow+\mathrm{S}^{2-}+2 \mathrm{H}_{2} \mathrm{O}
\end{gathered}
$$

A series of BSR actions will promote calcium ions in water to form calcium carbonate crystals, which are conducive to the positive direction of the reaction. From the south to the north in the coal mine of the area, the cation of $\mathrm{Ca}^{2+}$ decreases from $57.8 \%$ to $21.2 \%$ of deep confined water, which confirms the above reaction process. The underground (spring) water in the area mostly is alkaline water, and the $\mathrm{H}_{2} \mathrm{~S}$ is soluble in water, so there may be two ionization balance formulas shown in Equations $9-11$.

$$
\begin{gathered}
\mathrm{H}_{2} \mathrm{~S}+\mathrm{OH}^{-} \leftrightarrow \mathrm{HS}^{-}+\mathrm{H}_{2} \mathrm{O}, \mathrm{HS}^{-}+\mathrm{OH}^{-} \leftrightarrow \mathrm{S}^{2-}+\mathrm{H}_{2} \mathrm{O} \\
\mathrm{H}_{2} \mathrm{~S} \leftrightarrow \mathrm{H}^{+}+\mathrm{HS}^{-}, E_{1}=\mathrm{c}\left(\mathrm{H}^{+}\right) \cdot \mathrm{c}\left(\mathrm{HS}^{-}\right) / \mathrm{c}\left(\mathrm{H}_{2} \mathrm{~S}\right)=5.7 \times 10^{-8} \\
\mathrm{HS}^{-} \leftrightarrow \mathrm{H}^{+}+\mathrm{S}^{2-}, E_{2}=\mathrm{c}^{\prime}\left(\mathrm{H}^{+}\right) \cdot \mathrm{c}\left(\mathrm{S}^{2-}\right) / \mathrm{c}\left(\mathrm{HS}^{-}\right)=1.2 \times 10^{-15}
\end{gathered}
$$

In above equations, the $E_{1}, E_{2}$ is an ionization equilibrium constant of $\mathrm{H}_{2} \mathrm{~S}$ and $\mathrm{HS}^{-}$. $c\left(\mathrm{H}^{+}\right), c\left(\mathrm{HS}^{-}\right)$is the concentration of $\mathrm{H}^{+}$and $\mathrm{HS}^{-}$, which is ionization produced by $\mathrm{H}_{2} \mathrm{~S}$. $c\left(\mathrm{H}_{2} \mathrm{~S}\right)$ is the $\mathrm{H}_{2} \mathrm{~S}$ concentration of unionized. $c^{\prime}\left(\mathrm{H}^{+}\right), c\left(\mathrm{~S}^{2-}\right)$ is the concentration of $\mathrm{H}^{+}$ and $S^{2-}$, which is ionization produced by $H S^{-}$. According to the Equation 10 and Equation 11, a relationship between molar ratio of three form sulfur with $\mathrm{pH}$ value in the aqueous solution can be drawed, shown in Figure 3. So, with the rising of sulfide $\left(\mathrm{H}_{2} \mathrm{~S}\right)$ content, the concentration of $\mathrm{HS}^{-}$increases respectively, and so does the concentration of $\mathrm{OH}^{-}$with the hydrolysis of $\mathrm{HS}^{-}$, namely, the increase of $\mathrm{pH}$ value can also promote the further ionization or dissolution of $\mathrm{H}_{2} \mathrm{~S}$, further then the solution of $\mathrm{H}_{2} \mathrm{~S}$ prompts the continuous increase of content of $\mathrm{S}^{2-}$. Thereby, the formation water in this region goes into a cyclic process in which the amount of sulfide content $\left(\mathrm{H}_{2} \mathrm{~S}\right)$ raises continuously and a process in which the $\mathrm{pH}$ value will rise slowly. 


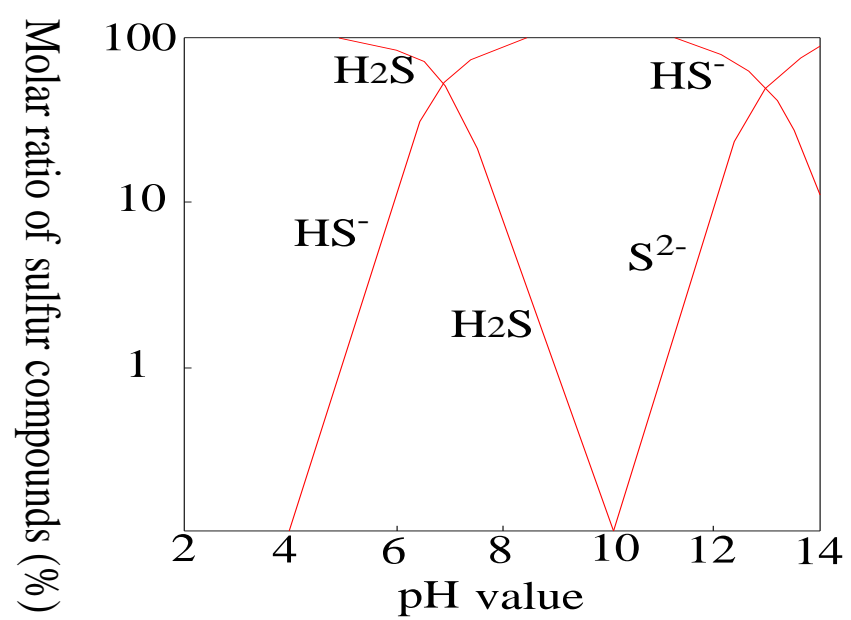

Figure 3. The relationship between molar ratio of sulfur with $\mathrm{pH}$ value

After recharging the surface water (ice and snow), the groundwater flows centripetally from the south to the north and gradually flows into the deep. At the same time, the poor continuity of the surrounding rock sand body leads to the slow or stagnant of the underground water in the coal bearing area. Therefore, up-escaping $\mathrm{H}_{2} \mathrm{~S}$ was blocked in the coal rock. Meanwhile, the slow motion of groundwater carrying $\mathrm{H}_{2} \mathrm{~S}$ to deep migration is blocked, which results in $\mathrm{H}_{2} \mathrm{~S}$ abundant enrichment in the coal rock and water. In the vicinity of the fault, the formation water is blocked and the water containing $\mathrm{H}_{2} \mathrm{~S}$ is exposed to the surface. The formation mode of $\mathrm{H}_{2} \mathrm{~S}$ in the region is shown in Figure 4.

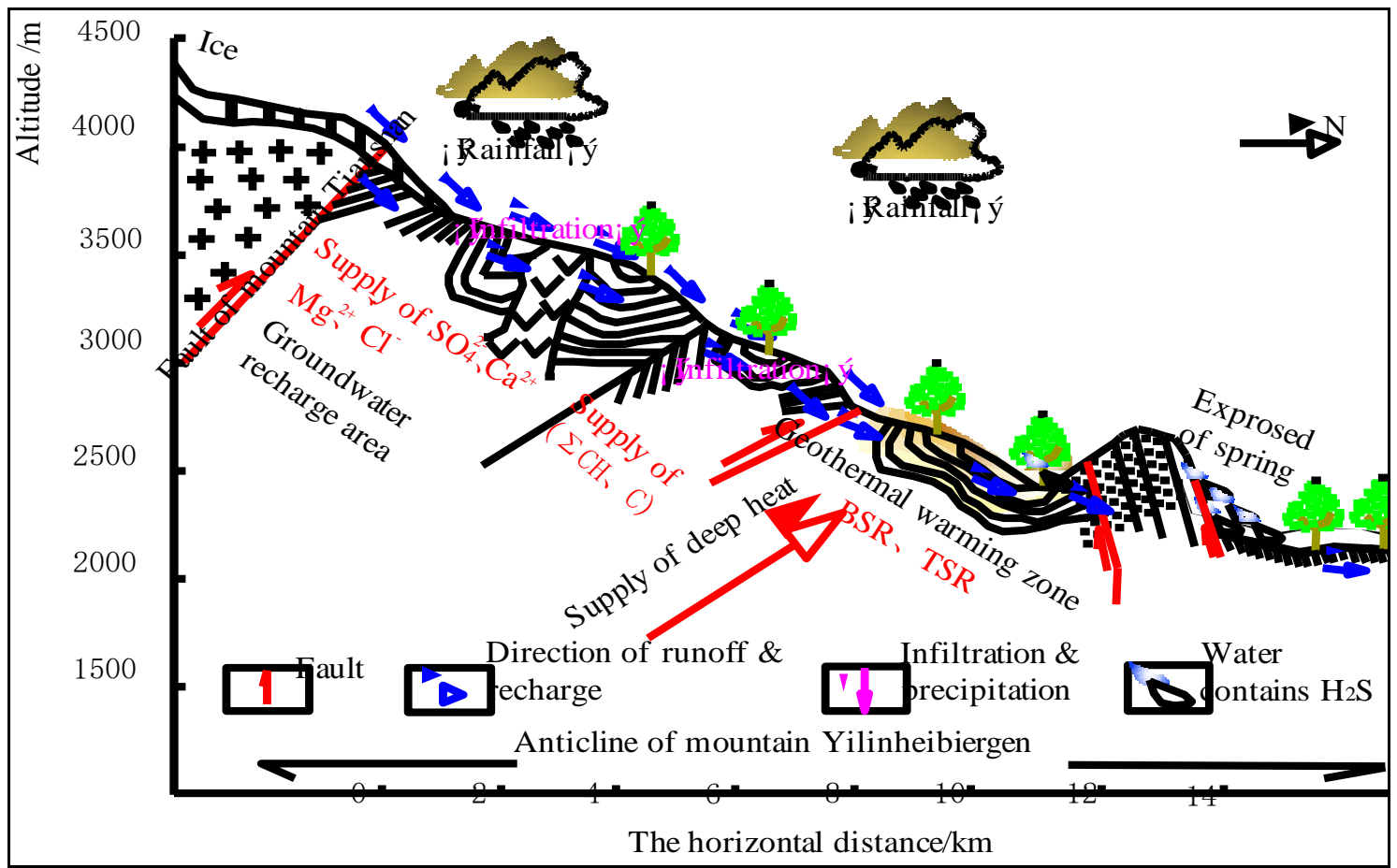

Figure 4. Formation mode of $\mathrm{H}_{2} \mathrm{~S}$ in study area 


\section{Control factors of $\mathrm{H}_{2} \mathrm{~S}$ accumulation}

\section{Control effect of regional structure on $\mathrm{H}_{2} \mathrm{~S}$ accumulation}

Palaeotectus and neotectonics are two main factors controlling $\mathrm{H}_{2} \mathrm{~S}$ distribution and reservoir (Zhu et al., 2006; Cai et al., 2009). The southeastern margin of Junggar basin, as the succession of depression structure of Mesozoic and Cenozoic, experienced polycyclic tectonic, deposited a thick deposit of source reservoir cap assemblage, created many sets of $\mathrm{H}_{2} \mathrm{~S}$-friendly source reservoir cap assemblage, and formed a variety of favorable gas traps. The forelang thrust belt structure leads to the strong extrusion, the universal development of the reverse fault, the coexistence of the anticline and the fractures or the cut from the fractures, which is indusive to the preservation of $\mathrm{H}_{2} \mathrm{~S}$. Due to the compression and torsion of the Himalayan movement, the closed-architectural structure of the study area was mainly characterized by broken anticline traps and broken nose traps with the main features of more layers, larger areas, and higher closure. There are many inversion tectonic movements in the region, and the anticline formed by reverse structure is directly covered by the sag of $\mathrm{H}_{2} \mathrm{~S}$ in the raw storage, which is beneficial to the preservation of $\mathrm{H}_{2} \mathrm{~S}$. The long-term faults caused by various tectonic movements provide the necessary access and extensive storage space for $\mathrm{H}_{2} \mathrm{~S}$ migration, which is beneficial to the reservoir of $\mathrm{H}_{2} \mathrm{~S}$.

Regional tectonic movement controls the distribution of $\mathrm{H}_{2} \mathrm{~S}$ reservoir. The development of structure has created many favorable traps of gas. Abundant source rocks have provided a solid material foundation for the formation of $\mathrm{H}_{2} \mathrm{~S}$. The depression structure has created favorable geological conditions for $\mathrm{H}_{2} \mathrm{~S}$ reservoir. Therefore, the region has a good configuration relationship in the space of $\mathrm{H}_{2} \mathrm{~S}$ generation, migration and enrichment conditions (source reservoir cap assemblage).

\section{Control effect of the development of caprock on $\mathrm{H}_{2} \mathrm{~S}$ accumulation}

The performance of the caprock in the study area is relatively stable and there are three sets of favorable reservoir and caprock combinations. In each layer, shorelacustrine, fluvial and delta facies are widely developed, and there widely exist sandstone, siltstone and alluvial fan conglomerate, glutenite and other coarse detrital deposits. Among them, the Mesozoic coal source is the main source rock, with the basic feature of self-generated self-storage combination. In the Sangonghe formation, the Xishanyao formation and the Toutunhe formation of Jurassic, the reservoir lithology is a proven good reservoir which mainly are fine sandstone and quartz feldspar lithic sandstone and mixed sandstone. The porosity of each coal seam in the south of Changji is $0.21 \sim 16.42 \%$ and the average is $8.41 \%$. The permeability is between $0.22 \times 10^{-}$ ${ }^{3} \sim 23.2 \times 10^{-3} \mathrm{um}^{2}$, the average is $11.6 \times 10^{-3} \mathrm{um}^{2}$. The porosity of each coal seam in the Liuhuanggou mining area is $4.12 \sim 15.91 \%$ and the average is $8.71 \%$ and the average permeability is $2.12 \times 10^{-3} \mathrm{um}^{2}$. The average porosity of each coal seam in the east of the Urumchi river is $8.51 \%$, the average permeability is $5.36 \times 10^{-3} \mathrm{um}^{2}$ and the physical characteristics of the regional reservoir are shown in Table 1 (Deng, 2015; Deng et al., 2017) The reservoir is mainly composed of intergranular pores and intragranular dissolved pores with the characteristics of medium porosity and low permeability reservoir, fractured pore type and the low cap rock permeability. It is clear that the regional medium - good reservoir has a wide range of distribution, which provides a broad favorable space for the reservoir of $\mathrm{H}_{2} \mathrm{~S}$. 
Table 1. Reservoir bed properties of foreland thrust belt in study area

\begin{tabular}{|c|c|c|c|c|}
\hline Horizon & Lithology & $\begin{array}{c}\text { Average } \\
\text { thickness (m) }\end{array}$ & $\begin{array}{c}\text { Porosity } \\
(\%)\end{array}$ & $\begin{array}{c}\text { Permeability } \\
\left(10^{-3} \mathbf{u m}^{2}\right)\end{array}$ \\
\hline $\begin{array}{l}\text { Tugulu group } \\
\left(\mathrm{K}_{1} \operatorname{tg}\right)\end{array}$ & $\begin{array}{l}\text { Mainly with purple red, gray green mudstone } \\
\text { and siltstone }\end{array}$ & $449 \sim 1525$ & 6.60 & 18.86 \\
\hline $\begin{array}{l}\text { Kalazha formation } \\
\qquad\left(\mathrm{J}_{3} \mathrm{k}\right)\end{array}$ & $\begin{array}{c}\text { Gray, yellow massive gray wacke, siltstone are } \\
\text { cross bedding }\end{array}$ & $50 \sim 750$ & 16.12 & 122.30 \\
\hline $\begin{array}{l}\text { Qigu formation } \\
\qquad\left(\mathrm{J}_{3} \mathrm{q}\right)\end{array}$ & $\begin{array}{l}\text { Brown red, purple red mudstone with purple } \\
\text { red, gray green sandy mudstone and tuff }\end{array}$ & $183 \sim 824$ & 9.53 & 15.38 \\
\hline $\begin{array}{l}\text { Toutunhe formation } \\
\qquad\left(\mathrm{J}_{2} \mathrm{t}\right)\end{array}$ & $\begin{array}{l}\text { Variegated sandy mudstone, sandstone and fine } \\
\text { conglomerate }\end{array}$ & $210 \sim 804$ & 10.49 & 57.51 \\
\hline $\begin{array}{l}\text { Xishanyao formation } \\
\qquad\left(\mathrm{J}_{2} \mathrm{X}\right)\end{array}$ & $\begin{array}{l}\text { Grey green, yellow, black \& gray fine } \\
\text { sandstone, siltstone, sandstone and coal seam }\end{array}$ & $380 \sim 1080$ & 7.91 & 0.16 \\
\hline $\begin{array}{l}\text { Sangonghe formation } \\
\qquad\left(\mathrm{J}_{1} \mathrm{~S}\right)\end{array}$ & $\begin{array}{l}\text { Gray, gray yellow, green mudstone, sandstone, } \\
\text { a small number of thin coal seams }\end{array}$ & $565 \sim 782$ & 8.31 & 5.13 \\
\hline $\begin{array}{l}\text { Badaowan formation } \\
\qquad\left(\mathrm{J}_{1} \mathrm{~b}\right)\end{array}$ & $\begin{array}{l}\text { Sandstone, siltstone, mudstone and thin coal } \\
\text { seam }\end{array}$ & $245 \sim 850$ & 9.00 & 3.25 \\
\hline $\begin{array}{l}\text { Xiaoquangou group } \\
\left(\mathrm{T}_{2+3} \mathrm{Xq}\right)\end{array}$ & $\begin{array}{l}\text { miscellaneous sand, muddy debris, and the } \\
\text { lower part of coarse clastic rock and } \\
\text { miscellaneous sandstone }\end{array}$ & $500 \sim 1000$ & 5.95 & 0.15 \\
\hline
\end{tabular}

According to the observation and data collection of the fracture from the original coal seam, the fissure development characteristics of the original coal seam are shown in Table 2 (Deng, 2015; Deng et al., 2017). The fracture of coal seam mostly is primary structure. The distribution of fracture density is up to $(50 \sim 250) / \mathrm{m}$ with the good openess and connectedness of the fracture. Most of them are not filled with minerals, which increase the permeability of coal seams. Hence, it provides a favorable space for the migration and storage of $\mathrm{H}_{2} \mathrm{~S}$ in coal seams.

Table 2. Fractured situation of raw coalbed in area

\begin{tabular}{|c|c|c|c|c|c|}
\hline Observation point & Type of coal and rock & Fracture group & Fracture frequency & Length (cm) & High $(\mathbf{c m})$ \\
\hline Xishan & $\begin{array}{c}\text { Bright and semi bright } \\
\text { coal }\end{array}$ & $\begin{array}{c}\text { Main fissure } \\
\text { Secondary fissure }\end{array}$ & $\begin{array}{l}18 \mathrm{strip} / 10 \mathrm{~cm} \\
6 \mathrm{strip} / 10 \mathrm{~cm}\end{array}$ & $>10.0$ & $\begin{array}{c}4 \sim 7 \\
<1\end{array}$ \\
\hline Dapugou & Bright coal & $\begin{array}{c}\text { Main fissure } \\
\text { Secondary fissure }\end{array}$ & $\begin{array}{l}25 \mathrm{strip} / 15 \mathrm{~cm} \\
22 \mathrm{strip} / 8 \mathrm{~cm}\end{array}$ & $\begin{array}{c}>10.0 \\
0.2 \sim 4.0\end{array}$ & $\begin{array}{l}2 \sim 5 \\
<1\end{array}$ \\
\hline Shengli & Semi bright coal & Main fissure & $\begin{array}{l}7 \text { strip } / 10 \mathrm{~cm} \\
9 \text { strip } / 10 \mathrm{~cm}\end{array}$ & 27.0 & $3 \sim 8$ \\
\hline $\begin{array}{l}\text { Qianshui river } \\
\text { mining area }\end{array}$ & $\begin{array}{c}\text { Bright coal } \\
\text { Semi bright coal }\end{array}$ & $\begin{array}{c}\text { Main fissure } \\
\text { Secondary fissure } \\
\text { Main fissure } \\
\text { Secondary fissure }\end{array}$ & $\begin{array}{l}15 \mathrm{strip} / 15 \mathrm{~cm} \\
22 \mathrm{strip} / 10 \mathrm{~cm} \\
10 \mathrm{strip} / 10 \mathrm{~cm} \\
8 \text { strip } / 10 \mathrm{~cm}\end{array}$ & $\begin{array}{c}25.0 \\
0.3 \sim 3.0 \\
>10.0\end{array}$ & $\begin{array}{l}>10 \\
<1 \\
1 \sim 4 \\
<1\end{array}$ \\
\hline
\end{tabular}

It is known that the development of the coal and rock type from bright to semi bright, half dark and dim in microfissures gradually diminishes. The coal seams in the region are mainly bright coal and semi-bright coal, indicating that regional coal reservoirs are conducive to the accumulation of $\mathrm{H}_{2} \mathrm{~S}$ in coal reservoirs. 
The lithology combination of the coal seam roof and bottom is classified into two categories. The first type is coarse clastic rock, including conglomerate, coarse sandstone and medium sandstone. The second type is fine clastic rock, including siltstone, mudstone, and shale. According to the classification method mentioned above, the results of the lithology of the roof and floor of the main coal seams in the region are shown in Figure 5.

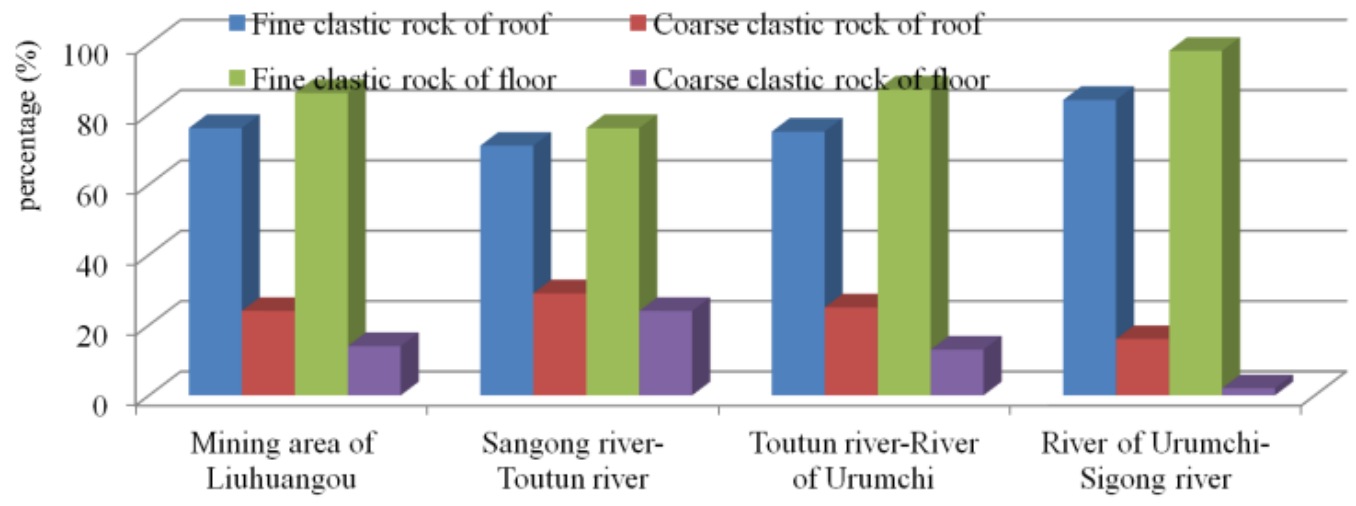

Figure 5. Proportions schematic of roof and floor lithological in regional coal seam

It is shown that the ratio of top and bottom microclastic rock accounts for over $67.2 \%$, and the bottom plate from the Urumchi river to Sigong river reaches $98.1 \%$. In the Toutun river area and the Liuhuanggou mining area, the proportion of roof clastics are $75.4 \%$ and $76.2 \%$, respectively and the ratio of clastic rock are $87.0 \%$ and $86.3 \%$ in the bottom plateau. It is known that the roof and bottom slate of the coal seam mainly composed of microclastic rock is a low permeability barrier layer with poor permeability and good sealing condition. Therefore, the combination of the roof and bottom slate in the regional of Jurassic coal seam is an effective combination of source reservoir cap assemblage of $\mathrm{H}_{2} \mathrm{~S}$.

\section{Control effect of buried depth and ground temperature on $\mathrm{H}_{2} \mathrm{~S}$ accumulation}

The contents of hydrogen sulfide and gas were determined by sampling in different buried coal seam of Xishan coal mine in 2013. When the coal seam depth is less than $350 \mathrm{~m}$, the content of gas and $\mathrm{H}_{2} \mathrm{~S}$ is generally small in each coal mine. When the buried depth is less than $420 \mathrm{~m}$, the methane concentration in the gas components is generally less than $80 \%$. When the buried depth is more than $420 \mathrm{~m}$, the methane fraction of the gas is more than $80 \%$, indicating that the depth of the coal seam gas weathering zone is about $420 \mathrm{~m}$. When the buried depth of coal seam is more than $650 \mathrm{~m}$, the content of gas and $\mathrm{H}_{2} \mathrm{~S}$ increases rapidly. With the increase of buried depth of coal seam, the gas content of coal seam becomes better, the component of methane rises and the content of $\mathrm{H}_{2} \mathrm{~S}$ becomes larger. It shows that the content of $\mathrm{H}_{2} \mathrm{~S}$ has a positive correlation with the buried depth.

Barker and Pawlewicz established the relationship between the maximum paleo temperature and the vitrinite reflectance of coal (Barker and Pawlewicz, 1986):

$$
\operatorname{Ln} R_{0}=0.0078 * T_{\max }-1.2
$$


In the formula, $R_{0}$ is the vitrinite reflectivity of coal, $T_{\max }$ is the maximum paleo temperature. The isoline of the region $R_{0}$ distribution feature is shown in Figure 6. It can be deduced that the maximum paleogeo-temperature range of the coal formation stage is approximately between $80.0{ }^{\circ} \mathrm{C}$ and $110.0^{\circ} \mathrm{C}$.

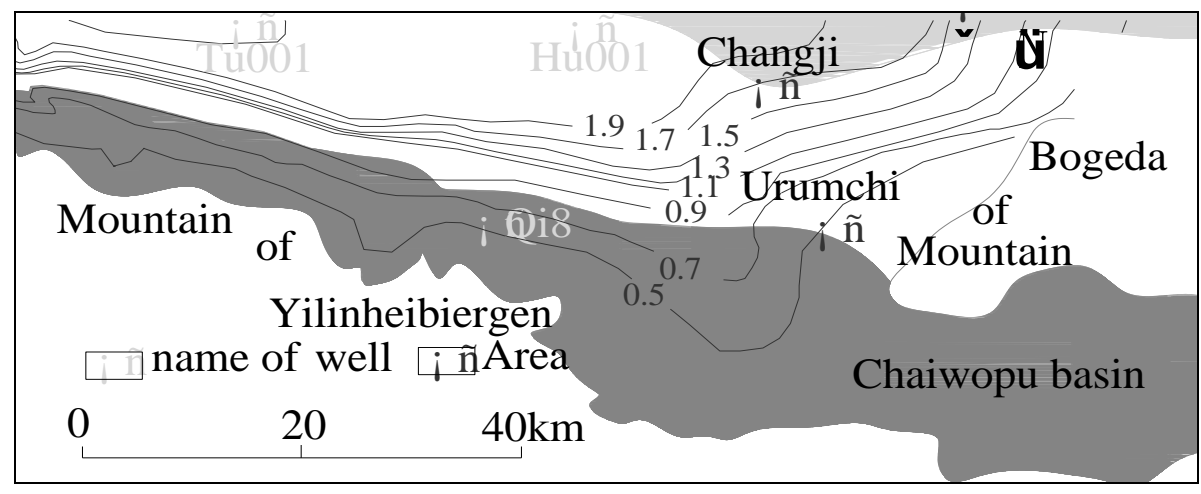

Figure 6. Choropleth of vitrinite reflectance of coal

The current geotempreture gradient in the region is $(1.4 \sim 2.0){ }^{\circ} \mathrm{C} / 100 \mathrm{~m}$ (Guo, 2010; Wang et al., 2000). It can be inferred that the temperature distribution of the $3000 \mathrm{~m}$ coal rock layer in the current depth is shown in Figure 7. The depth of coal seam buried at present is generally $200 \sim 1500 \mathrm{~m}$ and the geotempreture is less than $45^{\circ} \mathrm{C}$, which is beneficial to the reproduction of SRB.

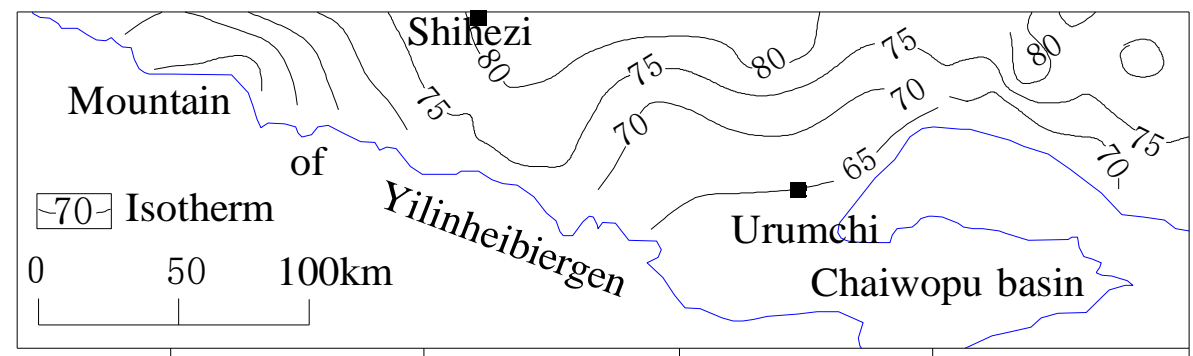

Figure 7. Contours of temperature in $3000 \mathrm{~m}$ depth of Junggar basin

\section{Control effect of groundwater on $\mathrm{H}_{2} \mathrm{~S}$ accumulation}

The attitude of water storage structure in the front of the piedmont is influenced by neotectonic. The activity of groundwater affects the enrichment and migration of $\mathrm{H}_{2} \mathrm{~S}$. The basement of the regional plain mainly consists of two kinds of groove settlement and uplift, as shown in Figure 8. In the piedmont depression or fault zone, a huge sandgravel layer (aquifer) was accumulated in the Quaternary Period. And above and below the coal-bearing strata of Xishanyao formation, there are good water-retaining layers. The water converges into the basin depression under the action of gravity, resulting in a stagnant and closed state of the groundwater in the coal reservoir within the zone. The $\mathrm{H}_{2} \mathrm{~S}$ is sealed and stored under the effect of hydrodynamic sealing and gas control.

The salinity of underground water of regional coal mine is between $1.2 \mathrm{~g} / \mathrm{L}$ and 7.1 $\mathrm{g} / \mathrm{L}$ with the feature of weak alkaline. In Toutunhe basin, along the runoff direction, the hydrochemical types of groundwater are evolved into $\mathrm{HCO}_{3}-\mathrm{SO}_{4}-\mathrm{Cl}-\mathrm{Na}$ by $\mathrm{HCO}_{3}-\mathrm{Ca}$ - 
$\mathrm{Na}$ and $\mathrm{HCO}_{3}-\mathrm{SO}_{4}-\mathrm{Na}-\mathrm{Ca}$, with the main components of $\mathrm{NaHCO}_{3}$. Salinity and hardness increase from low to high, salinity rapidly from less than $1.0 \mathrm{~g} / \mathrm{L}$ to more than $7.0 \mathrm{~g} / \mathrm{L}$; and the pH, from 8.1 to 9.3 (Duan et al., 2007; Tian et al., 2017; Li et al., 2016; Chen et al., 2013). The chemical characteristics of the groundwater in each coal mine (area) from the south to north basin are shown in Table 3 (Deng, 2015; Deng et al., 2017). $\mathrm{NaHCO}_{3}$ type-water often indicates stable water environment. Water formed under the environmental conditions of the mainland is also a sign of oil in the oil and gas fields and one of the important symbols of reducing environment, which indicates that the underground aquifers are in a reducing environment in the region.

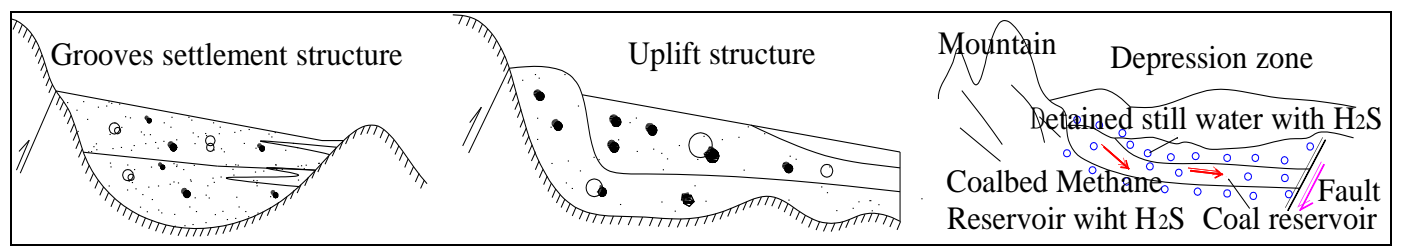

Figure 8. Changes schematic of piedmont base and hydrodynamic action of coal bed methane

Table 3. Groundwater chemical characteristics

\begin{tabular}{c|c|c|c|c}
\hline Mining area & Daxigou area & Qianshui river area & $\begin{array}{c}\text { Liuhuanggou mining } \\
\text { area }\end{array}$ & Xishan coal mine \\
\hline Hydrochemical type & $\mathrm{SO}_{4}-\mathrm{Cl}-\mathrm{HCO}_{3}-\mathrm{Ca}$ & $\mathrm{SO}_{4}-\mathrm{Cl}-\mathrm{Na}$ & $\mathrm{SO}_{4}-\mathrm{Cl}-\mathrm{K}+\mathrm{Na}$ & $\mathrm{Cl}_{-}-\mathrm{SO}_{4}-\mathrm{K}+\mathrm{Na}$ \\
Salinity $(\mathrm{g} / \mathrm{L})$ & 1.1 & 1.6 & 3.5 & 6.2 \\
$\mathrm{H}_{2} \mathrm{~S}$ content $(\mathrm{mg} / \mathrm{L})$ & $7.89 \sim 25.32$ & $9.26 \sim 51.29$ & $23.89 \sim 69.45$ & $41.89 \sim 259.63$ \\
$\mathrm{pH}$ & 8.3 & 8.5 & 8.5 & 9.0 \\
\hline
\end{tabular}

\section{Accumulation model of $\mathrm{H}_{2} \mathrm{~S}$}

Geological structure controls the source reservoir cap assemblage of hydrogen sulfide. Under special geological conditions, two types of $\mathrm{H}_{2} \mathrm{~S}$ accumulation patterns are formed in the region of the northward monoclinic and the imbricated fan-shaped.

\section{$\mathrm{H}_{2} \mathrm{~S}$ accumulation model of northward monoclinic}

The north single oblique $\mathrm{H}_{2} \mathrm{~S}$ accumulation model is widely distributed in the east of Urumchi. Hydrogen sulfide accumulation is mostly controlled by hydrogeological conditions. The monoclinic south-wing collects the water from rivers and glaciers. The environment of the detention zone of well sealed, the high degree of groundwater salinity and the poor water flow is conducive to the proliferation of SRB. On the water vapor (solid) interface, the occurrence of $\mathrm{BSR}$ action forms $\mathrm{H}_{2} \mathrm{~S}$, then it is dissolved into water or diffused into the gas, and it migrates with the flow of water to the deep part of the coal bedrock (Cross et al., 2004; Krouse et al., 1988; Cody et al., 2000; Wei et al., 2014). Meanwhile, the poor continuity of the surrounding rock sand-body causes the slowness or the stagnant of the groundwater of the coal-bearing areas. Therefore, the $\mathrm{H}_{2} \mathrm{~S}$ diffusing upward in coal rock will be blocked. At the same time, the slowness of groundwater carries $\mathrm{H}_{2} \mathrm{~S}$ to the deep part and $\mathrm{H}_{2} \mathrm{~S}$ will be blocked, resulting in anomalous enrichment of $\mathrm{H}_{2} \mathrm{~S}$ in coal rock and water (Zhu et al., 2010; Zhu et al., 2014; Dai et al., 2004; Qiao et al., 2005). The $\mathrm{H}_{2} \mathrm{~S}$ accumulation model of northward monoclinic is shown in Figure 9. 


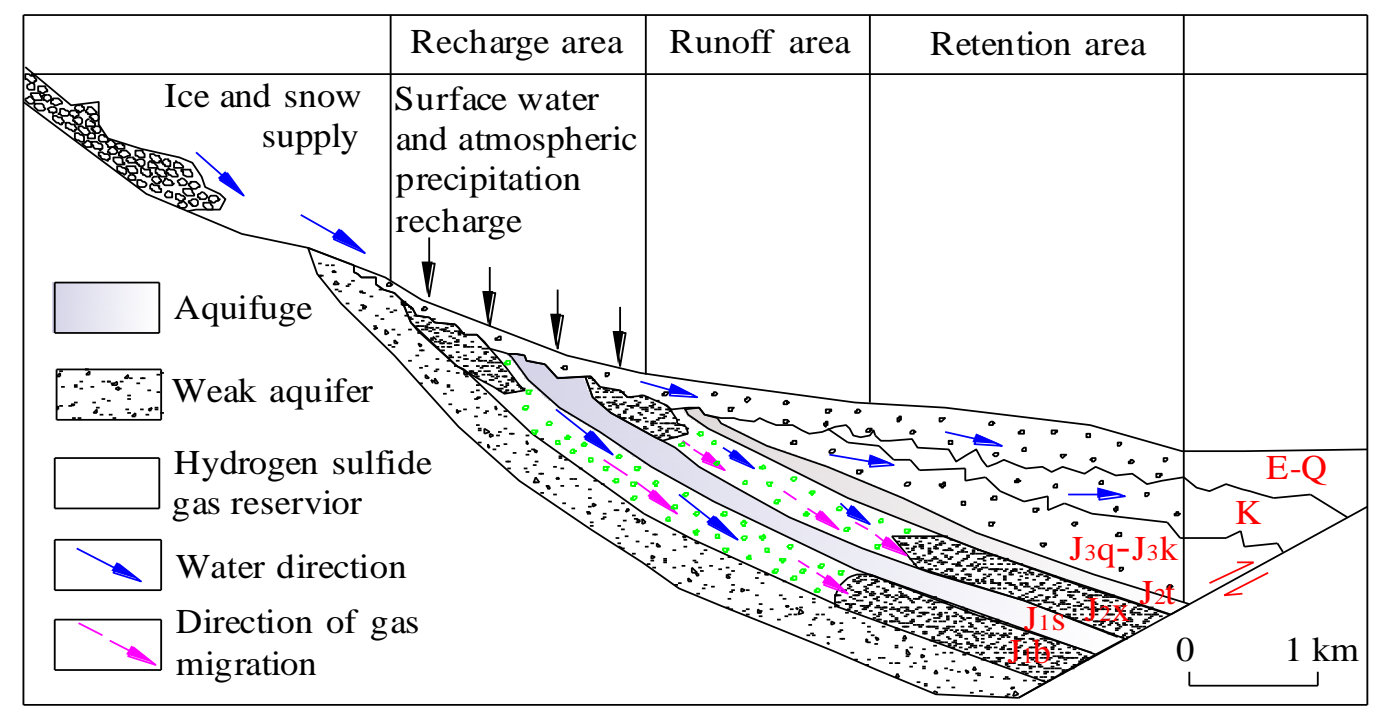

Figure 9. $\mathrm{H}_{2} \mathrm{~S}$ accumulation model of northward monoclinic

\section{$\mathrm{H}_{2} \mathrm{~S}$ accumulation mode of imbricate type}

The imbricate pattern of $\mathrm{H}_{2} \mathrm{~S}$ accumulation mainly occurs in the Xishan coal mine area of west Urumchi. The area is affected by Urumchi -Miquan strike slip fault, which developes trust nappe structure belt. It is a kind of fracture where one side of the fracture breaks perpendicular to the fracture surface. The most obvious structural feature is echelon anticline distribution, which is in a strong, imbricate pattern (Fan et al., 2012; Wang et al., 2013; Deng et al., 2002; Xu et al., 2001; Qu et al., 2009; Fang et al., 2006). It is shown in Figure 10.

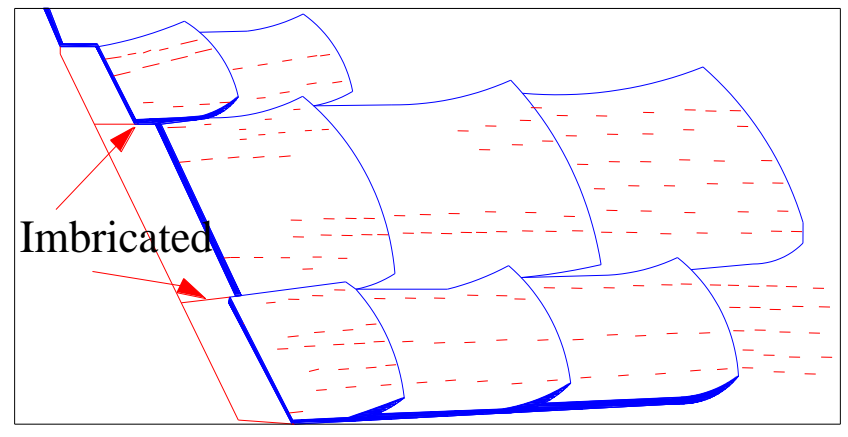

Figure 10. The schematic diagram of imbrication

The $\mathrm{H}_{2} \mathrm{~S}$ is produced by the action of BSR. Part of $\mathrm{H}_{2} \mathrm{~S}$ meets the metal ions and reacts with them and form a new product. Part of $\mathrm{H}_{2} \mathrm{~S}$ is integrated into the water, which moves slowly to the deep and forms hydrosulphuric acid so that the water is rich in $\mathrm{H}_{2} \mathrm{~S}$. Part of $\mathrm{H}_{2} \mathrm{~S}$ is mixed into the gas of coal and rock strata, vertical or longitudinal migration along the gas source fracture to the depression part, resulting in an abnormal $\mathrm{H}_{2} \mathrm{~S}$ enrichment in coal rock strata. Most of the regional faults are relatively independent structural systems and are mainly thrust faults. The $\mathrm{H}_{2} \mathrm{~S}$ accumulates of imbricated fan-shaped is shown in Figure 11. 


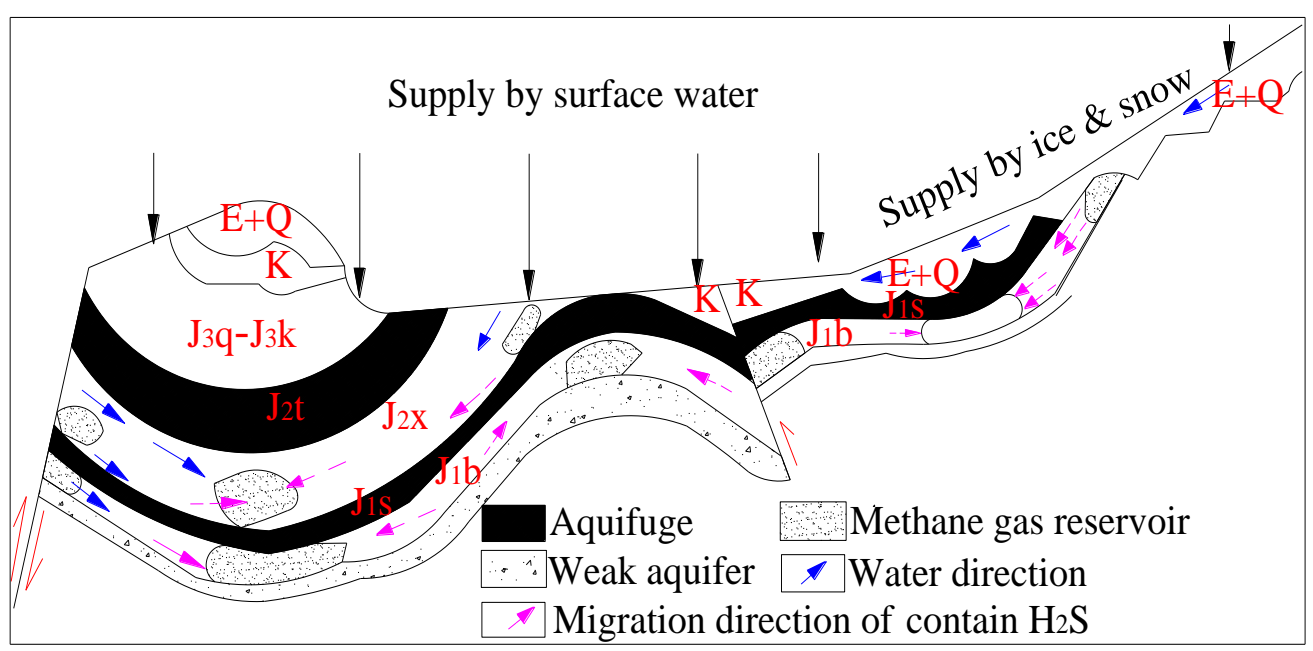

Figure 11. $\mathrm{H}_{2} \mathrm{~S}$ accumulation model of imbricated fan-shaped

\section{Discussion}

BSR, TSR and magmatic activity are the main genetic types of hydrogen sulfide in coal mine. The genetic recognition pattern of hydrogen sulfide in coal mine can be established according to the characteristics of coal environment, coal rock thermal evolution history and gas composition.

The depth of coal seam buried at present is generally $200 \sim 1500 \mathrm{~m}$ and the geotempreture is less than $45^{\circ} \mathrm{C}$, which is beneficial to the reproduction of SRB. Along with the runoff direction, the salinity and $\mathrm{pH}$ value of groundwater gradually increase.

According to the characteristics of reservoir lithology, chemical characteristics of groundwater, temperature of coal-series strata, analysis of gas component, bacterial detection of SRB, the BSR is prone to occur and is likely to form the $\mathrm{H}_{2} \mathrm{~S}$. However, coal fire in this region has a long history and part of $\mathrm{H}_{2} \mathrm{~S}$ may be produced by the burning of coal-series strata, which needs futher identification.

\section{Conclusion}

The hydrogen sulfide are abundant anomaly in many coal mines (districts) in southeastern margin of Junggar basin in China. There are three sets of source rocks in the Tugulu formation of Lower Cretaceous, Middle-Lower Jurassic and Middle Permian in the region. Most of the buried depth of coal seams are 200 1500 $\mathrm{m}$ and the temperature of the formation is less than $45{ }^{\circ} \mathrm{C}$, which is beneficial to the propagation of SRB. The average SRB value of samples is 791 grams / sample. Along the runoff direction, the salinity and $\mathrm{pH}$ value of groundwater gradually increase. And the hydrochemical types of groundwater are evolved into $\mathrm{HCO}_{3}-\mathrm{SO}_{4}-\mathrm{Cl}-\mathrm{Na}$ by $\mathrm{HCO}_{3}-\mathrm{Ca}-$ $\mathrm{Na}$ and $\mathrm{HCO}_{3}-\mathrm{SO}_{4}-\mathrm{Na}-\mathrm{Ca}$, with the main components of $\mathrm{NaHCO}_{3}$. In a reducing environment and the rich hydrocarbon, the BSR is prone to occur and is likely to form the $\mathrm{H}_{2} \mathrm{~S}$.

In the region, as the succession of depression structure of Mesozoic and Cenozoic, experienced polycyclic tectonic, deposited a thick deposit of source reservoir cap assemblage, created many sets of $\mathrm{H}_{2} \mathrm{~S}$-friendly source reservoir cap assemblage, and formed a variety of favorable gas traps. Meanwhile, the better pore types of the 
reservoir are mainly the intergranular pore and intragranular dissolved pore, which is a reservoir of medium porosity and low permeability. The top and bottom slate of coal seam are mainly composed of fine clastic rock and low permeability barrier with the characteristics of good sealing ability. Which provides a wide space for the reservoir of $\mathrm{H}_{2} \mathrm{~S}$, under the action of groove type subsidence structure, uplift type relief structures and the hydrodynamic control methane.

Under special geological conditions, there are two types of $\mathrm{H}_{2} \mathrm{~S}$ accumulation modes which are the northward monoclinic and the imbricated fan-shaped.

Acknowledgements. This work was supported by "National Natural Science Foundation of China (51774116, U1504403)", "Scientific and Technological Project of Department of Science \& Technology of Henan Province (182102210320, 19B620001)" and "Postdoctoral Research Fund of Henan Province (2017)". In the study process, the authors are also grateful to Professor Mingju Liu of Henan Polytechnic University for his ardent guidance and help.

\section{REFERENCES}

[1] Barker, C. E., Pawlewicz, M. J. (1986): The correlation of vitrinite reflectance with maximum temperature in humic organic metter. - Paleogeothermics. Lecture Notes in Earth Sciences. Springer Berlin Heidelberg 5: 79-93.

[2] Cai, C. F., Li, K, Ma, A., Zhang, C., Xu, Z., Worden, R. H., Wu, G., Zhang, B., Chen, L. (2009): Distinguishing the Cambrian source rock from the Upper Ordovician: evidence from sulfur isotopes and biomarkers in the Tarim basin. - Organic Geochemistry 40(7): 755-768.

[3] Chen, Y., Wang, X. T., Fang, S. H. (2013): Hydrodynamic characteristics of hydrocarbon accumulation in $\mathrm{E}_{1-2 \mathrm{Z}}$ of Huo-Tu structural belt, southern Junggar Basin, NW China. Journal of China University of Petroleum 37(03): 30-36,43.

[4] Cody, J. D., Hutcheon, I. E., Krouse, H. R. (2000): Fluid flow, mixing and the origin of $\mathrm{CO}_{2}$ and $\mathrm{H}_{2} \mathrm{~S}$ by bacterial sulphate reduction in the Mannville Group, Southern Alberta, Canada. Marine.Petroleum. - Fuel \& Energy Abstracts 41(2): 84.

[5] Cross, M. M., Manning, D. A. C., Bottrell, S. H., Worden, R. H. (2004): Thermochemical sulfate reduction (TSR): experimental determination of reaction kinetics and implications of the observed reaction rates for petroleum reservoirs. - Organic Geochemistry 35(4): 393-404.

[6] Dai, J. X., Hu, J. Y., Jia, C. Z. (2004): Suggestions for scientific and safety exploration and development of high hydrogen sulfide natural gas fields. - Petroleum exploration and development 31(2): 1-4.

[7] Deng, Q. D., Zhang, P. Z., Ran, Y. K. (2002): Basic characteristics of China's activities. Chinese science 32(12): 1021-1030.

[8] Deng, Q. G (2015): The study of genesis modes and enrichment control factors of hydrogen sulfide in Jurassic coal seam within the midst of southern margin of Junggar basin. - Henan Polyticnic University, China.

[9] Deng, Q. G., Liu, M. J., Cui, X. F., Wen, J. (2017): A study of hydrogen sulfide genesis in coal mine of southeastern margin of Junggar Basin. - Earth Science Frontiers 24(5): 395-401.

[10] Deng, Q., Wu, X., Wang, Y., Liu, M. (2018): Activity characteristics of sulfate reducing bacteria and formation mechanism of hydrogen sulfide. - Applied Ecology and Environmental Research 16(5): 6369-6383.

[11] Duan, L., Wang, W. K., Cao, Y. Q. (2007): Hydrochemical characteristics and formation of groundwater in the middle section of the north foot of the Tianshan Mountain. Journal of Arid Land Resources and Environment 21(9): 29-34. 
[12] Fan, G. X., Li, Z., Yang, D. S. (2012): Study on tectonic evolution of Qigu fault zoning belt. - Journal of Southwest Petroleum University 34(3): 9-17.

[13] Fang, S. H., Jia, C. Z., Guo, Z. J. (2006): Re-recognition of the Permian Basin Attributes in the Zhuner Basin and Its Tectonic Significance. - Geoscience front 13(3): 108-121.

[14] Fei, G. A., Zhu, G. Y., Zhang, Y. C. (2010): Global distribution hydrogen sulphidebearing natural gas and the major factors controlling its formation. - Earth Science Frontiers 17(1): 350-360.

[15] Fu, X. H., Wang, W. F., Yue, J. H. (2006): Genesis analyses of $\mathrm{H}_{2} \mathrm{~S}$ gas abnormity in gas of Bayi coalmine in Zaozhuang. - Journal of China Coal Society 31(2): 206-210.

[16] Guo, P. Y. (2010): Characteristics of geothermal field of deep mine heat damage control in China. - China University of Mining \& Technology, Beijing.

[17] Guo, J. G., Wang, X. L., Pang, X. Q. (2013): Evaluaton and hydrocarbon expulsion characteristics of the Middle-Lower Jurassic source rock in the southern margin of Junggar basin. - Journal of China University of Mining \& Technology 42(4): 595-605.

[18] Headd, B., Engel, A. S. (2013): Evidence for niche partitioning revealed by the distribution of sulfur oxidation genese collected from areas of a terrestrial sulfide spring with differing geochemical conditions. - Appl Environ Microbiol 79(4): 1171-1182.

[19] Krouse, H. R., Viau, C. A., Eliuk, L. S., Ueda, A., Halas, S. (1988): Chemical and isotopic evidence of thermochemical sulfate reduction by light hydrocarbon gases in deep carbonate reservoirs. - Nature 333: 415-419.

[20] Li, Y., Cao, D., Wei, Y., Wang, A., Zhang, Q., Wu, P. (2016): Middle to low rank coalbed methane accumulation and reservoiring in the southern margin of Junggar Basin. - ACTA PETROLEI SINICA 37(12): 1472-1482.

[21] Liu, M. J., Deng, Q. G., Zhao, F. J. (2012): Origin of hydrogen sulfide in coal seams in China. - Safety Science 50(4): 668-673.

[22] Machel, H. G. (2001): Bacterial and thermochemical sulfate reduction in diagenetic settings old and new insights. - Sedimentary Geology 140(1-2): 143-175.

[23] Qiao, X. Y., Wang, W. K., Chen, Y. (2005): Characteristics of water storage structure and water cycle in the northern foot of Tianshan Mountains. - Journal of Earth Sciences and Environment 27(3): 33-37.

[24] Qin, S. B. (1987): Geotectonic problems in the southern margin of the Junggar Basin. Xinjiang Petroleum Geology 02: 6-13.

[25] Qu, G. S., Ma, X. J., Chen, X. F. (2009): On the Structure and Evolution of the Junggar Basin. - Xinjiang Petroleum Geology 30(1): 1-6.

[26] Tian, J. J, Yang, S. G. (2011): Sequence strata and coal accumulation of lower and middle Jurassic formation from southern margin of Junggar Basin, Sinkiang, China. Journal of China Coal Society 36(1): 58-64.

[27] Tian, X. R., Zhuo, Q. G., Zhang, J., (2017): Sealing capacity of the Tugulu Group and its significance for hydrocarbon a accumulation in the lower play in the southern Junggar Basin, northwest China. - Oil \& Gas Geology 38(02): 334-344.

[28] Wang, S. J., Hu S. B., Wang, J. Y. (2000): The Characteristics of Heat Flow and Geothermal Field in Junggar Basin. - Chinese Journal of Geophysics 43(6): 816-824.

[29] Wang, T. B., Jia, D., Wei, D. T. (2013): Mesozoic positive and negative structural analysis of the southern margin of the Junggar Basin. - Geological science 48(1): 176190.

[30] Wei, J. J., Deng, Q. G., Liu, M. J. (2014): Hydrogen sulfide prevention and treatment technology research of coal mine. - Coal technology 33(10): 269-272.

[31] Worden, R. H., Smalley, P. C., Oxtoby, N. H. (1995): Gas souring by thermochemical sulfate reduction at $140{ }^{\circ} \mathrm{C}$. - AAPG Bulletin 79(6): 854-863.

[32] Xu, Y., Liu, F. T., Liu, J. H. (2001): Deep Characteristics of the Collision Zone in Western China and Its Dynamic Significance. - Journal of Geophysics 44(1): 40-47. 
[33] Zhu, G. Y., Zhang, Y. C., Ma, Y. S., (2006): Effectiveness thermochemical sulfate reduction on oil and gas industry a $\mathrm{H}_{2} \mathrm{~S}$ formation accelerating development of the secondary pores in reservoirs. - Earth Science Frontiers 13(3): 141-149.

[34] Zhu, G. Y., Zhang, S. C., Zhang, B. (2010): Marine carbonate reservoir types and accumulation patterns in the central and western regions of China. - Journal of Petroleum 31(6): 871-878.

[35] Zhu, G. Y., Fei, A. G., Zhao, J. (2014): Characteristics and Mechanism of Sulfur Isotope Fractionation of TSR Genesis $\mathrm{H}_{2}$ S. - Journal of Rock 30(12): 3772-3786. 